\title{
Knowledge Level of Healthcare Professionals on Basic and Advanced Life Support in Children
}

\author{
(1) Özlem Tolu Kendir ${ }^{1}$, (1) Adnan Barutçu², (1) Hasan Özdemir ${ }^{3}$, (1) Sultan Bent ${ }^{3}$, (1) Özden Özgür Horoz ${ }^{4}$
}

1Department of Pediatric Emergency Care Unit, Akdeniz University Faculty of Medicine, Antalya, Turkey

${ }^{2}$ Clinic of Pediatrics, Halfeti State Hospital, Șanlıurfa, Turkey

${ }^{3}$ Cengiz Gökçek Maternity and Children Hospital, Gaziantep, Turkey

${ }^{4}$ Department of Pediatric Intensive Care Unit, Çukurova University Medical Faculty, Adana, Turkey

\begin{abstract}
Aim: This study aimed to determine the knowledge level of nurses, emergency medical technicians, and paramedics about the basic and advanced life support guidelines in children.

Materials and Methods: The study was conducted between July 2018 and August 2018, with 602 volunteer healthcare professionals, in Gaziantep of Turkey province of Turkey where the pediatric population is high. Following the 2015 guidelines of the American Heart Association, a questionnaire about basic and advanced life support in children and demographic data was administered. Statistical comparisons were made between the groups.

Results: Of the 602 participants, $62 \%$ were male. The average age of the participants was 28.4 (minimum-maximum, 18-50) years. The basic and advanced knowledge scores of the nurses were lower than those of the emergency medical technicians and paramedics. Those who work in pediatric emergency departments and pediatric intensive care units, with 5-8 years of experience, and paramedics had high advanced life support scores and total knowledge scores. The basic life support knowledge scores and total knowledge scores of those with certification were good, but the advanced life support knowledge score was inadequate.

Conclusion: The basic and advanced life support knowledge scores of the professionals were moderate, and the total knowledge scores of the nurses working in pediatric services were low. While basic life support knowledge scores of the paramedics and professionals working in emergency departments and child intensive care units were low, their advanced life support knowledge scores were high.

Keywords: Basic life support in children, advanced life support in children, nurse, emergency medical technician, paramedics
\end{abstract}

\section{Introduction}

Cardiac arrest; It is the cessation of respiratory and cardiac activity for many reasons, especially respiratory problems in children. Cardiopulmonary resuscitation (CPR); defined as life-saving procedures for airway safety and respiratory and circulatory support following cardiac arrest (1).

According to the American Heart Association (AHA) guidelinesBasic Life Support (BLS) guideline, children (between 28 days and 18 years old) who do not respond to environmental stimuli, are not breathing or breathing poorly, have no central pulse, or have a central pulse $\leq 60$ /minute should be evaluated within a maximum of 10 seconds; help should be called, respiratory and compression support should be started and applied synchronously (1-3). When there is a rescuer, 30 chest compressions, and in case of double rescuer, 15 chest compressions followed by 2 breaths should be applied. During each compression, the rib cage should be collapsed at $1 / 3$ depth and allowed to stand back to create an effective pulse in the patient. Chest compression should be 100-120/min for patients with advanced airway support. Patients should be ventilated asynchronously for $10 \mathrm{sec} / \mathrm{min}$ for each ventilation $(1,4)$. 
The goal of performing CPR is to reach the patient's previous quality of life $(1,4,5)$. With the developments in emergency care and first aid methods in children; It was reported that discharge after CPR reached from 24\% to 43\% (1,4-6). Early detection of the life-threatening situation in the child services and early warning of the emergency team, and the correct implementation of the first and emergency aid can increase the success of CPR and decrease mortality and sequela rates $(2,3,5)$. In some studies, it is stated that even if only effective compression is performed, success has increased by $10 \%$, and good neurological results can reach 60\% with high quality CPR application $(1,5,7)$.

Survival and neurological good results; the patient's age, comorbidity, time of arrest, time to first aid, adequacy of medical team and equipment, high quality CPR application and postresuscitative care are directly related (1,8-10). Turkey in practice in order to increase the success rate of CPR according to AHA guidelines, the children basic and advanced life support courses are organized and maintained the certification.

In this study, in Gaziantep province in Turkey where child population is high, it was aimed to determine the level of knowledge in nurses, emergency medicine technicians and paramedics who is dealing with pediatric patients according to the basic and advanced life support guide AHA-2015 Guide in children with the latest updates.

\section{Materials and Methods}

This study planned as a cross-sectional descriptor; Between July 2018 and August 2018, it was conducted in three big hospitals of Gaziantep Turkey (Gaziantep Cengiz Gökçek Gynecology and Pediatrics Hospital, Dr. Ersin Arslan Training and Research Hospital and 25 Aralık State Hospital). One of the study centers; the children's hospital accepts about 250,000 children patient per year; on the other hand, Dr. Ersin Arslan Training and Research Hospital and 25 Aralık State Hospital accept an average of 50,000-75,000 children patient per year. Nurses, emergency medical technicians and paramedics; who works in the child emergency departments, child intensive care units and child services of these hospitals and who works in the ambulance service and emergency health department operations and coordination center of the province were included in the study. Those who did not give care about pediatric patients and those who were temporarily assigned to these units from other centers were excluded from the study. Health workers other than nurses, emergency medical technicians and paramedics were excluded. The data were collected through a 16-question survey form. Descriptive features such as age, gender, occupational title, year of employment in the profession, the department they worked in and basic and advanced life support certification status; asked as multiple choice or open-ended questions. In the second part of the survey, the participants were asked ten multiple choice questions to measure their level of knowledge about basic and advanced life support in children. By giving "one point" to each information question that is answered correctly; basic life support evaluated by 5 points over 5 questions; advanced life support was evaluated 5 points over 5 questions and life support total knowledge level score was evaluated finally over 10 points. Based on the total score; It was evaluated as "0-2 points: bad, 3 points: medium, 4 points: good, 5 points: very good”. Knowledge level questions were prepared by the researchers with reference to the AHA 2015 guidelines-BLS (1). Permission was obtained from the institutions where the study was conducted in order to conduct the research. Ethics committee approval was obtained from the Local Non-Interventional Clinical Research Ethics Committee of Gaziantep University (no: 2019/148, date: 03.04.2019). The participants were informed about the study, their verbal and written consent was obtained and the study was completed on a voluntary basis.

\section{Statistical Analysis}

SPSS 23.0 package program was used for statistical analysis of the data. Categorical measurements were given as numbers and percentages, while continuous measurements were given as mean, deviation and minimum-maximum. The suitability of variables to normal distribution was evaluated using visual (histogram and probability plots) and analytical methods (Kolmogorov-Smirnov/Shapiro-Wilk tests). Mann-Whitney U test was used in binary variables and Kruskall-Wallis test was used in more than two variables. Bonferroni analysis was used in PostHoc analysis to determine the source of the difference between the groups. Spearman correlation analyzes were applied for correlation analysis between the scales. In all tests, $p<0.05$ was considered statistically significant in all tests.

\section{Results}

Seven hundred fifty healthcare professionals (HPS) who met the criteria of the study were reached, 602 of them voluntarily participated in the study. In the study, 378 (62\%) of the participants were male and the average age of all participants was 28.4 years (min-max: 18-50 years). On the other hand, nurses with 414 participants were $68.8 \%$ of whole group. Four hundred and thirty-three (73\%) of the participants had less than 8 years of experience in their fields. One hundred and fifty-two (25.2\%) of the participants had a basic and advanced life support certificate. Demographic characteristics of HPs are given in Table 1. The answers to basic and advanced life support questions and the evaluation of the scale scores used are given (Figure 1). 


\begin{tabular}{|c|c|c|c|}
\hline & & $n$ & $\%$ \\
\hline \multirow[t]{2}{*}{ Gender } & Female & 224 & 37.2 \\
\hline & Male & 378 & 62.8 \\
\hline \multirow{4}{*}{ Age (years) } & $\leq 23$ & 94 & 15.6 \\
\hline & $24-27$ & 212 & 35.2 \\
\hline & $28-32$ & 180 & 29.9 \\
\hline & $\geq 33$ & 116 & 19.3 \\
\hline \multirow{4}{*}{ Professional experiences } & $\leq 4$ & 261 & 43.4 \\
\hline & $5-8$ & 172 & 28.6 \\
\hline & $9-12$ & 89 & 14.8 \\
\hline & $\geq 13$ & 80 & 13.3 \\
\hline \multirow{3}{*}{ Professional title } & Nurse/health officer & 414 & 68.8 \\
\hline & Emergency medical technician & 89 & 14.8 \\
\hline & Paramedic & 99 & 16.4 \\
\hline \multirow[t]{2}{*}{ Have a basic and advanced life support certificate } & Yes & 152 & 25.2 \\
\hline & No & 450 & 74.8 \\
\hline \multirow{4}{*}{ Department } & $\begin{array}{l}\text { Emergency department-child intensive care } \\
\text { unit }\end{array}$ & 223 & 37.0 \\
\hline & General pediatric service & 214 & 35.5 \\
\hline & 112 operator service & 35 & 5.8 \\
\hline & Ambulance service & 130 & 21.7 \\
\hline & & mean $\pm S D$ & $\min -\max$ \\
\hline \multicolumn{2}{|l|}{ Age (years) } & $28.39 \pm 5.49$ & $18-50$ \\
\hline
\end{tabular}

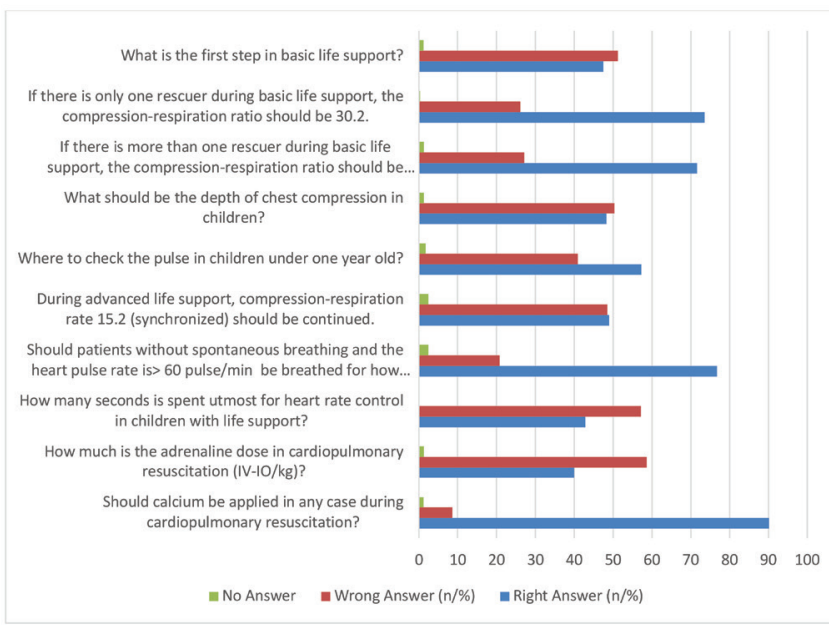

Figure 1. Distribution of knowledge questions by percentage of answers

A weak positive correlation was found between basic life support knowledge scores (BLSKS) and advanced life support knowledge scores (ALSKS) subscale dimensions $(r=0.256)$. It was determined that there was a strong positive correlation between BLSKS and the total knowledge scores (TKS) $(r=0.811)(p=0.001)$. There was also a strong positive correlation between the ALSKS subscale size and the TKS $(r=0.773)(p=0.001)$. Average values of scale scores are given in Table 2 .

Gender and scale scores of health professionals and their differences were not statistically significant $(p>0.05)$. The ALSKS [mean \pm standard deviation $(S D)=3.24 \pm 1.04$ ] and TKS (mean $\pm \mathrm{SD}=6.27 \pm 1.81$ ) of the HPs who aged 28 -32 years, were higher than the other groups, and these scores were found to be statistically significantly higher compared to other age groups ( $p=0.001, p=0.022$, respectively). The ALSKS (mean \pm $\mathrm{SD}=3.20 \pm 0.96)$ and TKS (mean $\pm \mathrm{SD}=6.33 \pm 1.71$ ) of those who have worked and experienced in their fields for 5-8 years are higher than the other groups, and the statistically significant difference is due to this group ( $p=0.017, p=0.027$, respectively). It was found that paramedics' BLSKS (mean $\pm S D=3.33 \pm 0.97$ ), ALSKS (mean $\pm S D=3.10 \pm 1.10)$ and TKS (mean $\pm S D=6.43 \pm 1.64$ ) of paramedics were higher than all other groups, and this difference was statistically was found to be significantly higher 
Table 2. Examining the scale scores used in the study

\begin{tabular}{|l|l|l|}
\hline & Mean \pm SD & Min-max \\
\hline Basic life support knowledge scores (BLSKS) & $2.98 \pm 1.18$ & $0-5$ \\
\hline Advanced life support knowledge scores (ALSKS) & $2.98 \pm 1.09$ & $0-5$ \\
\hline Total knowledge scores (TKS) & $5.97 \pm 1.80$ & $1-10$ \\
\hline min: Minimum, max: Maximum, SD: Standard deviation, n: Number & \\
\hline
\end{tabular}

( $p=0.000, p=0.049, p=0.009$, respectively). When the HPs with basic and advanced life support certificates are compared; It was observed that BLSKS was higher in those with certification, but ALSKS was not different between groups $(p=0.008, p=0.725$, respectively). While the BLSKS of those working in the ambulance service was higher, the ALSKS of those working in the emergency department-child intensive care units was higher. In Table 3, all the relationship between the demographic characteristics of HP and their scale scores is given. Eighty-three (54.6\%) of 152 healthcare workers with certificates were employed in the ambulance service; 194 (43.1\%) of 450 healthcare workers without certification were found to be working in the general services. Certification information is given in Table 4 according to the units in which HPs work.

\section{Discussion}

Our study is the first study which covers hospitals in a large city where have many of the child population. Also, our study included the largest participants in Turkey. Our results shows that the participants' who are young group with moderate experiences BLSKS and ALSKS are moderate. On the other hand, paramedics' ALSKS and TKS were "good" in terms of level. While the ALSKS of the HP working in the emergency departments and child intensive care units were good, thoughtfully, their BLSKS were insufficient. It was also determined that the HPs working in the general service had low TKS and the certification contributed positively to BLSKS and TKS, but had no effect on the ALSKS.

Nurses spend more time with the patient in the hospital services due to their duties. Paramedics and emergency medical technicians greet the patient first on the field. Therefore, they can only take part in the starting minutes of the CPR, which is directly related to the prognosis $(3,6)$. In the literature, it has been reported that the basic knowledge of CPR of nurses is lowmedium in general even in developed societies. Frequently CPR trainings have been pointed out (11-19).

The HPs between 28-32 ages are good at advanced knowledge score (AKS) and TKS. It can be explained by the fact that they were mostly working in the emergency departments and child intensive care units, and also have moderate (5-8 years) professional experience. It suggests that the hospitals' management may have made their plans especially in this direction in departments with dynamic functioning.

In this high-participation study shows that the professional experience has not made a difference in BLSKS. The professionals with moderate experience were better in ALSKS and TKS. This could be explained by the fact that the information has been obtained through more practice. It is found that the ALSKS of the HP working in the emergency departments and child intensive care units, which frequently encounter critical pediatric patients, is good and the BLSKS is insufficient. It can be explained by the fact that there are always doctors in these departments, airway safety is provided early and more advanced life support is provided. This also supports that information may have been acquired through practice. Unlike in the literature, Örsal et al. (20) study with the participation of 78 nurses stated that nurses have $>10$ years of experiences have higher BLSKS and ALSKS. Aygin et al. (21), study with the participation of 97 nurses stated that the knowledge level of nurses working in education and research hospitals was higher.

In our study, at all levels of knowledge of young and less experienced ( $<4$ years) HP does not make any difference, suggests that the information learned in schools may be forgotten in a short time. In the literature regarding CPR trainings, It was stated that the trainings contributed the knowledge of HP but the information gained was forgotten in a short time such as 3-6 months and it could not be reflected in the skill completely $(2,11,22-24)$. Similarly, Sener et al. (25) stated that school knowledge continued in the first years of graduation, but experience was at the forefront in the coming years.

Our study is composed of interested participants with pediatric patients only, it is the first study to compare different occupational groups on that issue in Turkey. The lower BLSKS of nurses than emergency medical technicians and paramedics suggests that they may not have updated critical patient management information in routine working conditions. Paramedics have higher advanced knowledge than other groups, it can be explained by their education is more focused on critical patients and they are more active in the critical field due to working conditions. Therefore, it may be beneficial to review the sections on critical child patient management in nursing education program. 
Table 3. Comparison of demographic features and scale scores of healthcare professionals

\begin{tabular}{|c|c|c|c|c|}
\hline & \multirow[t]{2}{*}{$\mathbf{n}$} & \multirow{2}{*}{$\begin{array}{l}\text { Basic life support } \\
\text { knowledge scores } \\
\text { Med (min-max) }\end{array}$} & \multirow{2}{*}{$\begin{array}{l}\text { Advanced life support } \\
\text { knowledge scores } \\
\text { Med (min-max) }\end{array}$} & \multirow{2}{*}{\begin{tabular}{|l|}
$\begin{array}{l}\text { Total } \\
\text { scores }\end{array}$ \\
Med (min-max) \\
\end{tabular}} \\
\hline & & & & \\
\hline \multicolumn{5}{|l|}{ Gender (u) } \\
\hline Female & 224 & $3(0-5)$ & $3(0-5)$ & $6(2-10)$ \\
\hline Male & 378 & $3(0-5)$ & $3(0-5)$ & $6(1-10)$ \\
\hline $\mathrm{p}$ & & 0.750 & 0.979 & 0.918 \\
\hline \multicolumn{5}{|l|}{ Age (years) (x2) } \\
\hline$\leq 23$ & 94 & $3(1-5)$ & $3(0-5)$ & $6(1-10)$ \\
\hline $24-27$ & 212 & $3(0-5)$ & $3(0-5)$ & $6(2-10)$ \\
\hline $28-32$ & 180 & $3(0-5)$ & $3(0-5)$ & $6(2-10)$ \\
\hline$\geq 33$ & 116 & $3(0-5)$ & $3(1-5)$ & $6(2-10)$ \\
\hline $\mathrm{p}$ & & 0.575 & 0.001 & 0.022 \\
\hline \multicolumn{5}{|l|}{ Professional experiences (x2) } \\
\hline$\leq 4$ & 261 & $3(0-5)$ & $3(0-5)$ & $6(1-10)$ \\
\hline $5-8$ & 172 & $3(0-5)$ & $3(1-5)$ & $6(3-10)$ \\
\hline $9-12$ & 89 & $3(0-5)$ & $3(1-5)$ & $6(2-10)$ \\
\hline$\geq 13$ & 80 & $3(0-5)$ & $3(0-5)$ & $6(2-10)$ \\
\hline $\mathrm{p}$ & & 0.318 & 0.017 & 0.027 \\
\hline \multicolumn{5}{|l|}{ Professional title $(\mathrm{x} 2)$} \\
\hline Nurse/health officer & 414 & $3(0-5)$ & $3(0-5)$ & $6(1-10)$ \\
\hline Emergency medical technician & 89 & $3(0-5)$ & $3(0-5)$ & $6(2-10)$ \\
\hline Paramedic & 99 & $3(1-5)$ & $3(0-5)$ & $6(2-10)$ \\
\hline $\mathrm{p}$ & & 0.000 & 0.049 & 0.009 \\
\hline \multicolumn{5}{|c|}{ Have a basic and advanced life support certificate $(\mathrm{u})$} \\
\hline Yes & 152 & $3(0-5)$ & $3(0-5)$ & $6(2-10)$ \\
\hline No & 450 & $3(0-5)$ & $3(0-5)$ & $6(1-10)$ \\
\hline $\mathrm{p}$ & & 0.008 & 0.725 & 0.029 \\
\hline \multicolumn{5}{|l|}{ Department (x2) } \\
\hline $\begin{array}{l}\text { Emergency department-child intensive } \\
\text { care unit }\end{array}$ & 223 & $3(0-5)$ & $3(1-5)$ & $6(2-10)$ \\
\hline General pediatric service & 214 & $3(0-5)$ & $3(0-5)$ & $6(1-10)$ \\
\hline 112 operator service & 35 & $3(0-5)$ & $3(1-5)$ & $6(2-9)$ \\
\hline Ambulance service & 130 & $3.5(0-5)$ & $3(0-5)$ & $6(2-10)$ \\
\hline$p$ & & 0.001 & 0.000 & 0.001 \\
\hline
\end{tabular}

\begin{tabular}{|c|c|c|c|c|c|}
\hline Certification & $\begin{array}{l}\text { Emergency department-child } \\
\text { intensive care unit } \\
\mathbf{n}(\%)\end{array}$ & $\begin{array}{l}\text { General service } \\
\mathrm{n}(\%)\end{array}$ & $\begin{array}{l}112 \text { operator } \\
\text { service } \\
\text { n (\%) }\end{array}$ & $\begin{array}{l}\text { Ambulance } \\
\text { service } \\
\mathbf{n}(\%)\end{array}$ & $\begin{array}{l}\text { Total } \\
\mathrm{n}(\%)\end{array}$ \\
\hline Yes & $33(21.7)$ & $20(13.2)$ & $16(10.6)$ & $83(54.6)$ & $152(25.2)$ \\
\hline No & $190(42.2)$ & $194(43.1)$ & $19(3.2)$ & 47 (10.4) & $450(74.8)$ \\
\hline Total & 223 & 214 & 35 & 130 & 602 \\
\hline
\end{tabular}


In Turkey, in order to increase the success rate of CPR practices, basic and advanced life support in children courses are organized and certification of health workers is done. According to our study, the certification programs have contributed positively to BLSKS and TKS. Therefore, repeated training activities can be more beneficial. On the other hand, the fact that having a certificate did not make a difference in ALSKS. It also suggests that educational activities are more focused on basic life support issues. It may be beneficial to expand the programs by including the evaluation of the course achievements with detailed feedback. On the other hand, facilitation of the transfer of information and the learning of team members could be done by planning of simulation-based trainings (26). Increasing the number of courses, updating the training program and holding case meetings involving the whole team can contribute to the improvement. These meetings could be a step in increasing the quality by strengthening team dynamics.

When the departments are analyzed, HPs (mostly nurses) working in the general pediatric service have a poor TKS compared to others. It is noticed that the renewal of knowledge during routine work is insufficient and they continue to their work with the former knowledge. We think that nurses should be more involved in training on critical patients and their motivation in this regard should be increased.

\section{Study Limitations}

The study reflects the knowledge level of HPs but does not include skills and self-assessments. The study shows only the results of HPs who work in those three large hospitals with high patient populations and working in the city's emergency health services of Gaziantep which is the one of major cities of Turkey. In addition, it does not reflect the knowledge levels of other HPs who do not care for pediatric patients and who do not work as nurses, emergency medical technicians and paramedics. It is also among the other limitations of the study that the HP who have a certificate could not learn the certificate update dates.

\section{Conclusion}

This study; It has shown that HPs' basic and advanced life support knowledge levels are not at the desired level. Also; It has shown that the knowledge levels of HPs working in different fields of hospitals are different from each other and that staffs do not follow up-to-date information about that. We think that the scope of trainings in both universities and hospitals should be revised and their frequency should be increased.

\section{Ethics}

Ethics Committee Approval: Ethics committee approval was obtained from the Non-Interventional Clinical Research Ethics Committee of Gaziantep University.(no: 2019/148, date: 03.09.2019)

Informed Consent: The participants were informed about the study, their verbal and written consent was obtained and the study was completed on a voluntary basis.

Peer-review: Externally peer-reviewed.

\section{Authorship Contributions}

Surgical and Medical Practices: Ö.T.K., H.Ö., S.B., Concept: Ö.T.K., Design: Ö.T.K., Data Collection or Processing: Ö.T.K., H.Ö., S.B., Analysis or Interpretation: Ö.T.K., A.B. Literature Search: Ö.T.K., Ö.Ö.H., Writing: Ö.T.K., A.B., Ö.Ö.H.

Conflict of Interest: No conflict of interest was declared by the authors.

Financial Disclosure: The authors declared that this study received no financial support.

\section{References}

1. de Caen AR, Berg MD, Chameides L, Gooden CK, Hickey RW, Scott HF, et al. Part 12: Pediatric Advanced Life Support: 2015 American Heart Association Guidelines Update for Cardiopulmonary Resuscitation and Emergency Cardiovascular Care. Circulation. 2015;132(18 Suppl 2):S526-42.

2. Girotra S, Spertus JA, Li Y, Berg RA, Nadkarni VM, Chan PS; American Heart Association Get With the Guidelines-Resuscitation Investigators. Survival trends in pediatric in-hospital cardiac arrests: an analysis from Get With the Guidelines-Resuscitation. Circ Cardiovasc Qual Outcomes. 2013;6:42-9.

3. Matos RI, Watson RS, Nadkarni VM, Huang HH, Berg RA, Meaney PA, et al. Duration of cardiopulmonary resuscitation and illness category impact survival and neurologic outcomes for in-hospital pediatric cardiac arrests. Circulation. 2013;127:442-51.

4. Yılmaz HL, Karaböcüoğlu M. Çocuk Acil Tıp: Kapsamlı ve Kolay Yaklaşım. Editörler: Karaböcüoğlu M, Yılmaz HL, Duman M. Cilt II, İstanbul Tıp Kitapevi; İstanbul: 2012: p. 83-105

5. Vural M, Koşar MF, Kerimoğlu O, Kızkapan F, Kahyaoğlu S, Tuğrul S, et al. Cardiopulmonary resuscitation knowledge among nursing students: a questionnaire study. Anatol J Cardiol. 2017;17:140-5.

6. Güven DY, Karabulut N. Kardiyopulmoner resusitasyon eğitiminin Hemșirelerin bilgi düzeyine etkisi. Arch Health Sci Res. 2018;5:161-8.

7. Atkins DL, de Caen AR, Berger S, Samson RA, Schexnayder SM, Joyner BL Jr, et al. 2017 American Heart Association Focused Update on Pediatric Basic Life Support and Cardiopulmonary Resuscitation Quality: An Update to the American Heart Association Guidelines for Cardiopulmonary Resuscitation and Emergency Cardiovascular Care. Circulation. 2018;137:e1-6.

8. Lee J, Yang WC, Lee EP, Huang JL, Hsiao HJ, Lin MJ, et al. Clinical Survey and Predictors of Outcomes of Pediatric Out-of-Hospital Cardiac Arrest Admitted to the Emergency Department. Sci Rep. 2019;9:7032.

9. Atkins DL, Everson-Stewart S, Sears GK, Daya M, Osmond MH, Warden CR, et al. Epidemiology and outcomes from out-of-hospital cardiac arrest in 
children: the Resuscitation Outcomes Consortium Epistry-Cardiac Arrest. Circulation. 2009;119:1484-91.

10. Gök F, Kılıçaslan A, Topal A, Yavşan DM, Yosunkaya A. An assessment of the Current Knowledge of Nurses, Staffed in Intensive Care Units, About Airway Management and Basic Life Support. J Chest Dis Crit Care Med. 2014;1:56-60.

11. Bukiran A, Erdur B, Ozen M, Bozkurt AI. Retention of nurses' knowledge after basic life support and advanced cardiac life support training at immediate, 6-month, and 12-month post-training intervals: a longitudinal study of nurses in Turkey. J Emerg Nurs. 2014;40:146-52.

12. Josipovic P, Webb M, Grath IM. Basic life support knowledge of undergraduate nursing and chiropractic students. J Adv Nurs. 2008;26:58-63.

13. De Regge M, Calle PA, De Paepe P, Monsieurs KG. Basic life support refresher training of nurses: individual training and group training are equally effective. Resuscitation. 2008;79:283-7.

14. Smith KK, Gilcreast D, Pierce K. Evaluation of staff's retention of ACLS and BLS skills. Resuscitation. 2008;78:59-65.

15. Boonmak P, Boonmak S, Srichaipanha S, Poomsawat S. Knowledge and skill after brief ACLS training. J Med Assoc Thai. 2004;87:1311-4.

16. Shahrakivahed A, Masinaienezhad N, Shahdadi H, Arbabisarjou A, Asadibidmeshki E, Heydari M. The Effect of CPR Workshop on the Nurses' Level of Knowledge and Skill. Int Arc Med. 2015;8.

17. Hopstock LA. Cardiopulmonary resuscitation; use, training and selfconfidence in skills. A self-report study among hospital personnel. Scand J Trauma Resusc Emerg Med. 2008;16:18.

18. Einspruch EL, Lynch B, Aufderheide TP, Nichol G, Becker L. Retention of CPR skills learned in a traditional AHA Heartsaver course versus 30-min video self-training: a controlled randomized study. Resuscitation. 2007;74:476-86.
19. Munezero JBT, Atuhaire C, Groves S, Cumber SN. Assessment of nurses knowledge and skills following cardiopulmonary resuscitation training at Mbarara Regional Referral Hospital, Uganda. Pan Afr Med J. 2018;30:108.

20. Örsal Ö, Boğa SM, Kersu Ö. Acil ve Yoğun Bakım Servislerinde Çalıșan Hemşirelerin Temel ve İleri Kardiyak Yaşam Desteğine iliş̦kin Bilgi Düzeylerinin Değerlendirilmesi. IGUSABDER. 2017;3;203-20.

21. Aygin D, Açוl HC, Yaman Ö, Çelik M, Danç E. Hemșirelerin Kardiyopulmoner Resüsitasyon ve Güncel 2015 Kılavuz Bilgilerinin Değerlendirilmesi. Turk J Card Nur. 2018;9:7-12.

22. Brião Rda C, de Souza EN, de Castro RA, Rabelo ER. Cohort study to evaluate nursing team performance in a theoretical test after training in cardiopulmonary arrest. Rev Lat Am Enfermagem. 2009;17:40-5.

23. Papadimitriou L, Xanthos T, Bassiakou E, Stroumpoulis K, Barouxis D, lacovidou N. Distribution of pre-course BLS/AED manuals does not influence skill acquisition and retention in lay rescuers: a randomised study. Resuscitation. 2010;81:348-52.

24. Karahan A, Cerit B, Ak B, Çıtak N, Şahin S, Ayhan F. Hemşirelik öğrencilerinin temel yaşam desteği eğitiminden hemen ve üç ay sonra bilgi ve beceri düzeylerinin değerlendirilmesi. Türkiye Acil Tıp Dergisi. 2005;5:22-7.

25. Şener S, Güler V, Türkan H. Eğitim hastanesinde görev yapan hemşirelerin erişkin/pediatrik temel ve ileri yaşam desteği bilgi düzeyleri. Türkiye Acil Tıp Dergisi. 2004;4:155-9.

26. Twigg S. Clinical event debriefing: a review of approaches and objectives. Curr Opin Pediatr. 2020;32:337-42. 
Appendix 1. Knowledge Level of Healthcare Professionals on Basic and Advanced Life Support in Children

1. I participate in the survey on a voluntary basis.
A. Yes
B. No

2. Gender:
A. Female
B. Male

3. Your Professional Title:

A. Nurses/Health officer

B. Emergency Medical Technician

C. Paramedic

4. Your Age:

5. How many years have you been working in your profession?

6. Do you have a basic and advanced life support certificate for children?
A. Yes
B. No

7. In which unit are you working?

A. Hospital emergency-child intensive care unit

B. Hospital general pediatric service

C.112 operation service

D. Ambulance service

8. What is the first step in basic life support?

A. Look, listen, feel method

B. Calling for help, checking pulse and starting compression

9. Where is the pulse checked in children under one year old?
A. Carotid artery
B. Femoral-Brachial arteries
C. Dorsalis pedis artery
D. All

10. If there is only one rescuer during basic life support, the compression-respiration ratio should be $30: 2$.
A. Right
B. Wrong

11. If there is more than one rescuer during basic life support, the compression-respiration ratio should be 15:2.
A. Right
B. Wrong

12. What should be the depth of chest compressions in infants, except for children and infants?

A. Chest anterior posterior diameter should be 1/4 deep, $3 \mathrm{~cm}$, speed should be 100-120/min.

B. Front anterior posterior diameter should be $1 / 3$ deep, $4-5 \mathrm{~cm}$, speed should be $>100-120 / \mathrm{min}$

C. Chest anterior posterior diameter should be $1 / 3$ deep, $3 \mathrm{~cm}$, speed should be 100-120/min

D. Chest anterior posterior diameter should be $1 / 2$ in deep, 4-5 $\mathrm{cm}$, speed should be $100-120 / \mathrm{min}$

13. How many seconds can be spent for heart rate control in children who need life support?
A. $5 \mathrm{sec}$
B. $10 \mathrm{sec}$
C.15 sec

14. How many seconds should patients be breathed with a heart rate $>60 / \mathrm{min}$ and no spontaneous breathing?
A. 3-5 sec
B> $5 \mathrm{sec}$

15. During advanced life support, compression-respiration ratio should be continued at 15: 2 (synchronous).
A. Right
B. Wrong

16. How much is the dose of Adrenaline in cardiopulmonary resuscitation (IV-IO/ $\mathrm{kg})$ ?
A-) $1 \mathrm{mg} / \mathrm{kg}(1 / 10000>0.1 \mathrm{ml} / \mathrm{kg}=1 \mathrm{dzm} / \mathrm{kg} \mathrm{IV}-\mathrm{IO})$
B-) $0.1 \mathrm{mg} / \mathrm{kg}(1 / 10000>0.1 \mathrm{ml} / \mathrm{kg}=1 \mathrm{dzm} / \mathrm{kg}$ IV-IO)
C-) $0.01 \mathrm{mg} / \mathrm{kg}(1 / 10000>0.1 \mathrm{ml} / \mathrm{kg}=1 \mathrm{dzm} / \mathrm{kg}$ IV-IO)

17. Should calcium be applied in any case during cardiopulmonary resuscitation?
A. Yes
B. No

Thank you for your participation in the survey. 